\title{
Site-specific reproductive failure and decline of a population of the Endangered yellow-eyed penguin: a case for foraging habitat quality
}

\author{
S. D. King ${ }^{1}$, G. A. Harper ${ }^{2,4, *}$, J. B. Wrightt ${ }^{1,5}$, J. C. McInnes ${ }^{1,6}$, J. E. van der Lubbe ${ }^{1,7}$, \\ M. L. Dobbins ${ }^{3}$, S. J. Murray ${ }^{1}$, \\ ${ }^{1}$ Yellow-eyed Penguin Trust, PO Box 5409, Dunedin, New Zealand \\ ${ }^{2}$ Zoology Department, University of Otago, PO Box 56, Dunedin, New Zealand \\ ${ }^{3}$ Department of Conservation, PO Box 3, Stewart Island, New Zealand \\ ${ }^{4}$ Present address: Department of Conservation, PO Box 55, St Arnaud, New Zealand \\ ${ }^{5}$ Present address: 21 Henry Street, Te Anau, New Zealand \\ ${ }^{6}$ Present address: C/- 53 Aurum Cres., Ringwood Nth., Victoria 3134, Australia \\ ${ }^{7}$ Present address: 14 Mary St, Port Chalmers, New Zealand
}

\begin{abstract}
Sub-populations within species can exhibit differing population growth trajectories in relation to one another depending on various environmental factors. In threatened species, negative population growth in some sub-populations can ultimately cause the demise of the species; therefore, understanding causal factors of population change is critical to inform management aimed at reversing population declines. Feral house cats Felis catus are potential predators of Endangered yellow-eyed penguins Megadyptes antipodes and were considered the principal causal factor in the species' decline on Stewart Island/Rakiura, New Zealand. The number of yellow-eyed penguins breeding on Stewart Island is low relative to the number on close outlying islands, where cats are absent, and a census had recorded few juveniles on Stewart Island, suggesting poor reproductive success. Yellow-eyed penguin breeding attempts on the northern coast of Stewart Island and outlying islands were monitored for $5 \mathrm{yr}$, but predation by cats was not evident. Instead, disease, probably aggravated by starvation and poor dietary provisioning, was found to be a significant cause of chick mortality on Stewart Island. Reproductive success was consistently low there $(0-33 \%)$, in contrast to outlying islands $(27-76 \%)$. Little recruitment was recorded on Stewart Island, and the number of breeding pairs on the northern coast of Stewart Island declined by $27 \%$ between 1999 and 2008. Factors unique to the north coast of Stewart Island are believed to be adversely affecting nesting yellow-eyed penguins, as a similar decline was not recorded elsewhere on the island or on outlying islands.
\end{abstract}

KEY WORDS: Megadyptes antipodes $\cdot$ Feral cat $\cdot$ Population decline $\cdot$ Breeding success $\cdot$ Chick mortality $\cdot$ Starvation $\cdot$ Disease $\cdot$ 'Junk-food' hypothesis

Resale or republication not permitted without written consent of the publisher

\section{INTRODUCTION}

Identifying causal factors of population decline in endangered species is critical for their recovery and such decline is often due to multiple agents (Frederiksen et al. 2004, Jiguet et al. 2007, Long et al. 2007), affecting different sub-populations within a species (Ainley et al. 2003). This can result in differing population growth trajectories within a metapopulation, which ultimately determines the persistence of a species (Esler 2000).

Of the penguin species, the yellow-eyed penguin Megadyptes antipodes is among the most endangered, due to a small scattered population with lim- 
ited distribution (IUCN 2008) and decreasing numbers (ca. 1600 to 1800 pairs, D. Houston pers. comm.). It is a tall, distinctive, penguin of a monotypic genus and species, endemic to the southern South Island and Stewart Island/Rakiura, New Zealand, and its sub-Antarctic islands (Marchant \& Higgins 1990; our Fig. 1). Approximately 600 to 700 pairs breed in loose colonies around southern New Zealand, which are both geographically and genetically distinct from their sub-Antarctic conspecifics (Boessenkool et al. 2009). Most breeding areas in the southern South Island are monitored each year, and the population estimate for these areas $(470$ pairs) is considered reasonably accurate. Historical estimates for Stewart Island have varied from 470 to 600 pairs (McKinlay 2001) to 220 to 392 pairs (Darby 2003), while a recent survey found 178 pairs (Massaro \& Blair 2003), suggesting a decline. Factors known to contribute to population decline in yelloweyed penguins include fishery by-catch (Darby \& Dawson 2000) and human disturbance (Ellenberg et al. 2007), although disease, changes in marine conditions and habitat degradation by grazing animals have also been suggested (Darby 2003, Massaro \& Blair 2003, Browne et al. 2011). In yellow-eyed penguin chicks, mortality is mainly due to accidents,

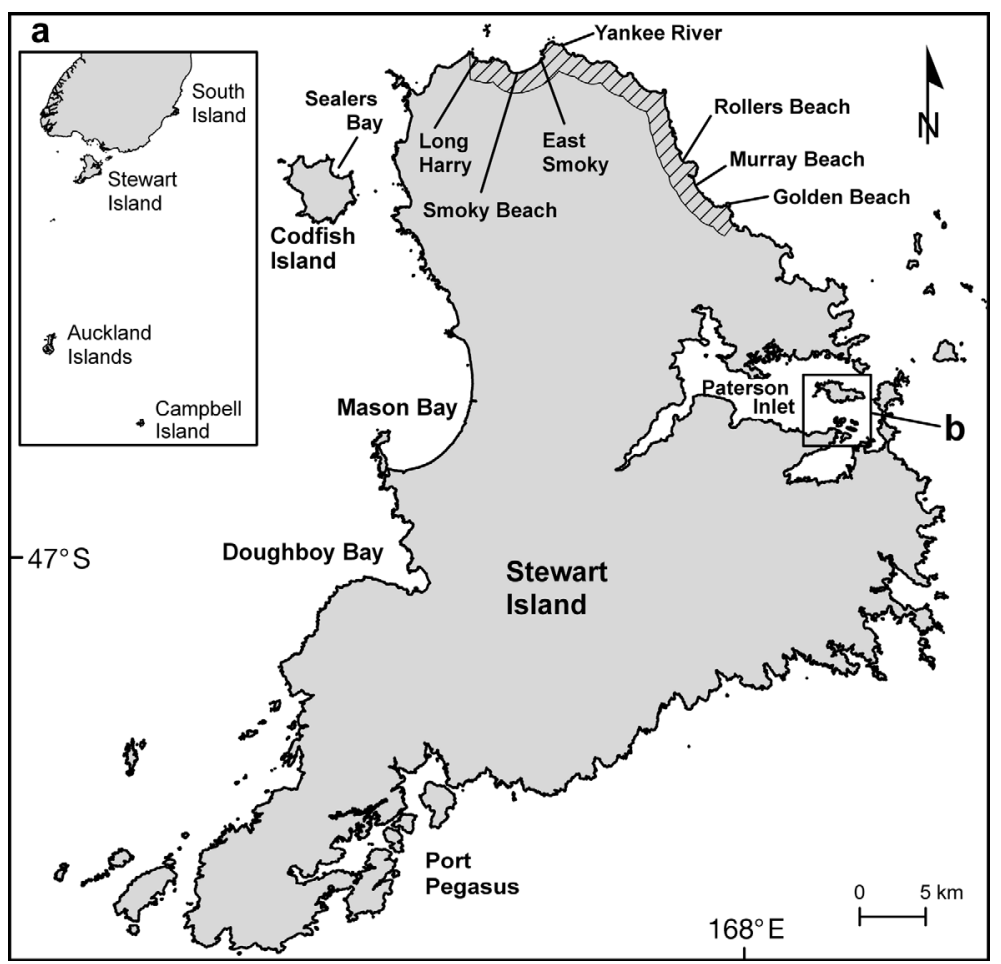

Fig. 1. Southern New Zealand and Stewart Island, showing islands and locations mentioned in the 'Materials and methods'. Box ' $b$ ' outlines the Bravo Islands starvation and depredation, the latter being the predominant cause. Introduced stoats Mustela erminea, ferrets $M$. furo and feral cats Felis catus are the principal predators in the South Island (Darby \& Seddon 1990). In this case, yellow-eyed penguins provide an excellent example of possible differing demographic constraints operating on sub-populations, on separate island colonies, that probably contribute to the overall reduction in the size of the metapopulation.

Penguins are excellent indicators of perturbations in the marine and terrestrial ecosystems in which they forage and breed. They are vulnerable to changes in habitat and climate in the sea and on land (Cunningham \& Moors 1994, Forcada et al. 2006, Hilton et al. 2006, Boersma 2008), predation by introduced species (Dann 1994), environmental damage (Bingham 2002), overfishing and fisheries by-catch (Bingham 2002, Taylor et al. 2002), disease (Morgan et al. 1985, Gardner et al. 1997) and increased human disturbance (Boersma 2008). Often, the agents of population decline in penguins are interwoven and no individual factor predominates. For example, the large Magellanic penguin Spheniscus magellanicus population at Punta Tombo, Argentina, has declined by $22 \%$ since 1987 due to a combination of climate change, environmental damage and human disturbance (Boersma 2008). As many penguin populations are in decline worldwide (Barbraud \& Weimerskirch 2001, Pütz et al. 2003, Hilton et al. 2006, Sander et al. 2007, Cuthbert et al. 2009), addressing causal factors is often an urgent priority before populations crash. Moreover, as near upper-trophic level consumers, penguins also act as 'canaries in the ecosystem coalmine', warning of damage to the marine environment (Boersma et al. 2009).

On Stewart Island/Rakiura (175000 ha), the southernmost of the 3 main islands of New Zealand, stoats and ferrets are absent but feral cats are widespread (Harper 2007). Recent surveys suggested that chick depredation by feral cats has been the main cause of an observed decline in the number of breeding pairs of yellow-eyed penguins on the island (Darby 2003). Of 178 pairs located in 1 survey, over half (99) were found on catfree islands (Massaro \& Blair 2003). The lack of juveniles seen on these surveys supported this assumption as this species 
is strongly philopatric (Massaro \& Blair 2003). Feral cats have been instrumental in the precipitous decline of other ground-nesting species on the island, namely the highly endangered kakapo Strigops habroptilus in the 1980s (Powlesland et al. 1995) and southern New Zealand dotterel Charadrius obscurus obscurus (Dowding \& Murphy 1993), and they also depredate blue penguins Eudyptula minor (Karl \& Best 1982, S. King pers. obs.).

A prima facie case existed for cat predation as the principal cause of the apparent difference in yellow-eyed penguin reproductive success and population decline between Stewart Island and its outlying islands. It was likely that the losses would have been caused by depredation during the postguard stage, when the chicks (>3 kg, Richdale 1957) are left by both adults so they can forage. During the guard stage, depredation of chicks under a large (ca. $5 \mathrm{~kg}$ ) and belligerent adult penguin by a cat was less likely. Our study had 2 main objectives. We sought first to update census data for the entire breeding population of the area and second, to determine the reasons for population change of yellow-eyed penguins at the 3 sites. The 3 causal factors were likely as follows: (1) Depredation by cats: if cats are in fact a causal factor in population decline, we expected to observe lower reproductive success on Stewart Island, where cats are present, than on other islands where cats are absent. (2) Death by disease or other causes: where obvious causes of death (e.g. predation) were not apparent, carcasses underwent post-mortem analysis because at least 2 diseases have been detected in New Zealand penguin species (Graczyk \& Cockrem 1995, Hocken 2000, Sturrock \& Tompkins 2008). (3) Poor food supply: data on chick food supply was determined using stable isotopes to investigate possible dietary factors in the decline. Stable isotopic analysis is now a well-established tool in assessing diet, trophic pathways and prey partitioning in marine birds, and penguins in particular (Inger \& Bearhop 2008, Mattern et al. 2009, Jaeger \& Cherel 2011). Stable isotopic analyses have the advantage over gut or faecal studies of providing an integrated signal of gross dietary composition over defined periods of an animal's life. The quantification of the source of assimilated, rather than just ingested, food items is also possible with this technique, so stable isotopic analyses (using carbon and nitrogen isotope ratios) was used to investigate differences in the diets of yellow-eyed penguins from colonies within $50 \mathrm{~km}$ of each other.

\section{MATERIALS AND METHODS}

\section{Study sites}

Stewart Island sits on a shallow continental shelf spanning $46^{\circ} 41^{\prime}$ to $47^{\circ} 17^{\prime} \mathrm{S}$ and $167^{\circ} 27^{\prime}$ to $168^{\circ} 14^{\prime} \mathrm{E}$. The western and southern coastline is exposed to prevailing winds and southern ocean swells, and is generally rugged and inaccessible due to steep rocky cliffs in many places. The northern and eastern coastline is less exposed and contains numerous sandy beaches and sheltered bays, as well as several inlets, of which Paterson Inlet is the largest. The island has over $700 \mathrm{~km}$ of coastline in total. Human settlement is limited to a small area on the northeast coast. The remainder of the island contains unbroken natural vegetation cover from lowland coastal forest to sub-alpine tops. Some modification of this vegetation occurs through browsing and grazing by introduced possums Trichosurus vulpecula and whitetailed deer Odocoileus virginianus borealis and red deer Cervus elaphus, which are widespread. The suite of introduced mammalian predators on Stewart Island is limited to 3 rat species (Rattus rattus, $R$. norvegicus, R. exulans) and feral cats (Harper 2007). A large number of smaller outlying islands surround the main island, ranging in size from less than 1 ha to 1400 ha.

Yellow-eyed penguins breed at numerous places along the northern and eastern coasts of Stewart Island. This study monitored 7 breeding places on the northern coast (Fig. 1), bordering the southern side of Foveaux Strait that separates Stewart Island from the South Island.

Of the outlying islands, the largest is Codfish Island/Whenua Hou (1400 ha), and is located $2 \mathrm{~km}$ off Stewart Island's north-west coast (Fig. 1). Introduced predators and browsers are absent. Codfish Island's western coastline is also exposed and rugged, while the northern and eastern coast is relatively sheltered and includes several small bays and a long sandy beach at Sealers Bay. A permanently manned Department of Conservation field base is located near this beach. The natural forest cover has largely recovered from attempts to farm cattle in the early 1900s, and from ca. 100 yr of possum browsing prior to their eradication. Yellow-eyed penguins breed in 3 bays on the northern and eastern sides of the island. We monitored yellow-eyed penguins within Sealers Bay, which contains the largest number of breeding pairs.

The Bravo Islands comprise 5 small (1 to 13 ha) islets within Paterson Inlet (Fig. 1). The group was 
treated as 1 site during this study. The islets are relatively sheltered, although only 1 islet has any significant sandy beaches. The coastlines are generally rocky, but each islet can be accessed by yellow-eyed penguins at up to 7 sites. The lowland coastal forest cover is intact and little modified. Deer are capable of swimming the short distance $(<1 \mathrm{~km})$ from the mainland, but are not permanently resident. Rats (unknown species) and weka Gallirallus australis scotti, a large native rail, are present on each islet, but feral cats and possums are absent.

\section{Population survey}

The first comprehensive population survey of yellow-eyed penguins on and around Stewart Island was carried out between 1999 and 2001 (Massaro \& Blair 2003). To detect population changes, the survey carried out in 1999 to 2001 was repeated in November to January 2008 to 2009. Breeding places recorded in the 1999 to 2001 survey were re-surveyed, and new places were searched for by walking stretches of accessible coastline, or cruising close inshore by boat, looking for evidence of penguin presence. When evidence of penguin presence was found, nests were located and recorded using methods described below ('Reproductive success'). Routes taken by searchers onshore and while cruising close inshore were recorded using GPS to enable repeat searches in the future.

\section{Reproductive success}

Reproductive success was defined as the proportion of chicks that fledge from the number of eggs laid. Yellow-eyed penguin nests on northern Stewart Island were located between mid-October and early November from 2003 to 2007, and on the cat-free outliers Codfish Island and the Bravo islands from 2004 to 2007. Accessible coastline at known breeding places was walked while looking for evidence of penguin presence. Indications included birds ashore, and footprints, faeces and claw marks, which become more numerous near the start of well-worn tracks entering the forest, denoting points of access and egress from nest sites to the ocean. These tracks were followed until a nest site classified as 'occupied' or 'recently used' was found. 'Occupied' was defined as having at least 1 adult with eggs or chicks present, and 'recently used' as evidence that the nest bowl had been occupied (a combination of signs such as a fresh latrine, dead chicks, abandoned eggs or egg shell fragments in the bowl) and used for a breeding attempt in the current season. All track forks and surrounding area were thoroughly investigated until searchers were satisfied that all nests associated with each track had been located. Each nest site was assigned an individual label, marked with tape on a nearby branch and recorded using GPS to facilitate relocation. The number of adult birds and nest contents (number of eggs or chicks) was recorded for each nest. If the exact number of eggs or chicks could not be determined at the time, or during subsequent visits to the nest site, the number of eggs laid was assumed to be 2 . If an egg was missing on subsequent visits it was assumed it had hatched and that the chick had died. Nests on Stewart Island were visited every 2 to $3 \mathrm{~d}$ from just prior to or just after hatching (early to mid-November) until chicks fledged in late February or early March. On Codfish Island and the Bravo Islands, logistical constraints meant that visits were less frequent, occurring at irregular intervals ranging from 1 to $6 \mathrm{wk}$. At each visit, the number of attendant adults and number of eggs and/or chicks was recorded, and the condition of chicks noted. A search was made for missing chicks, and any carcasses retrieved were examined. At all study sites, chicks were weighed in early February to determine their pre-fledging weight and condition. Captured chicks were weighed in a cloth bag using a Pesola $10 \mathrm{~kg}$ spring balance. A clean, disinfected bag was used at each nest to reduce the risk of disease transfer between nests. The eyes, mouth and cloaca of chicks were checked for sign of abnormality or illness. Chicks that were not seen subsequent to weighing were considered to have fledged if they had weighed over $4 \mathrm{~kg}$.

As apparent changes in marine and climatic conditions from year to year can severely impact breeding success and the number of pairs of yellow-eyed penguins breeding in any given year (Richdale 1942, Efford et al. 1994), breeding success data were gathered over 5 yr to account for these likely changes in productivity.

\section{Factors affecting reproductive success}

Unhatched eggs and chick carcasses were retrieved to assess causes of failure (i.e. depredation, starvation, disease). When a carcass was intact but in an advanced state of decomposition, depredation was excluded as a cause of death, but the actual cause was recorded as unknown. Carcasses that 
were only slightly or moderately decomposed were either sent intact to the Institute of Veterinary, Animal and Biomedical Sciences at Massey University, Palmerston North, New Zealand or, when field logistics prevented timely dispatch, $1 \mathrm{~cm}^{3}$ samples of heart, liver, lungs, kidney and spleen were collected, stored individually in $10 \%$ formalin solution and dispatched when convenient, accompanied by descriptive notes relating to the chick's condition, stomach contents, any other relevant observation and digital photographs. Unhatched eggs were also sent for examination to determine fertility.

To determine the factor(s) that had the most negative effect(s) on reproductive success, we used multiple regression models to examine the correlations of the various reasons for chick mortality during the guard stage (Table 1) in each year against nesting success each year (Fig. 2) as the response variable. For that purpose we fitted linear models, and the best model was selected using backward stepwise elimination of successive variables, using the log-likelihood ratio test as the step function (Harraway 1995). Statistical analyses were carried out using the programme ' $\mathrm{R}$ ' (Version 2.9, R Development Core Team 2011).

\section{Food supply}

To investigate the relationship between food supply and chick mortality, and to determine whether dietary differences existed between sites, samples of chick down were collected in 2006 and 2007 for stable isotope analyses. Approximately $1 \mathrm{~cm}^{3}$ of loosely packed down was cut from the backs of live chicks 20 to $25 \mathrm{~d}$ old. At this age, chicks are covered with secondary down that has replaced the primary down with which the chick hatched (Richdale 1957). Isotopic information within secondary down is therefore indicative of the chick's diet since hatching. Down was also plucked from chick carcasses. Each sample was labeled and stored individually in a small plastic bag. Sample analysis of 43 down samples from 2006 was carried out by Iso-Trace
New Zealand Ltd and of 30 down samples from 2007 by the GNS Science National Isotope Centre Rafter Laboratory in Lower Hutt, New Zealand.

Samples were freeze-dried and ground into a powder; lipids were then extracted using a chloroformmethanol rinse. Isotope ratios $\left({ }^{13} \mathrm{C} /{ }^{12} \mathrm{C}\right.$ and $\left.{ }^{15} \mathrm{~N} /{ }^{14} \mathrm{~N}\right)$ were measured using isotope ratio mass spectrometry (IRMS; Hydra ${ }^{\circledR}$ 20/20 mass spectrometer). Stable isotopes are expressed in $\delta$ notation (in parts per thousand; per mil; \%o) as follows:

$$
\delta \mathrm{X}(\% \mathrm{o})=1000 \times\left(R_{\text {sample }}-R_{\text {standard }}\right) / R_{\text {standard }}
$$

where $\mathrm{X}$ is the ratio of ${ }^{15} \mathrm{~N}$ to ${ }^{14} \mathrm{~N}$ or ${ }^{13} \mathrm{C}$ to ${ }^{12} \mathrm{C}$ and $R$ is the ratio ${ }^{15} \mathrm{~N}:{ }^{14} \mathrm{~N}$ or ${ }^{13} \mathrm{C}:{ }^{12} \mathrm{C}$ as measured for the samples and relevant standards (atmospheric $\mathrm{N}_{2}$ and

Table 1. Megadyptes antipodes. Causes of yellow-eyed penguin chick mortality during the guard stage at 3 sites on northern Stewart Island and nearby islands from 2003 to 2008

\begin{tabular}{|lccc|}
\hline \multirow{2}{*}{ Cause of mortality } & \multicolumn{3}{c}{ Number of chicks } \\
\cline { 2 - 4 } & $\begin{array}{c}\text { Stewart Island } \\
(2003-2008)\end{array}$ & $\begin{array}{c}\text { Bravo Islands } \\
(2004-2008)\end{array}$ & $\begin{array}{c}\text { Codfish Island } \\
(2004-2008)\end{array}$ \\
\hline Dead: carcass not found & 17 & 34 & 30 \\
Dead: predation ruled out & 55 & 5 & 16 \\
Accident/parental trauma & 12 & 0 & 1 \\
Disease & 16 & 3 & 0 \\
Starvation & 17 & 0 & 0 \\
Other & 5 & 0 & 3 \\
Unknown & 2 & 0 & 1 \\
Total & 124 & 42 & 51 \\
\hline
\end{tabular}

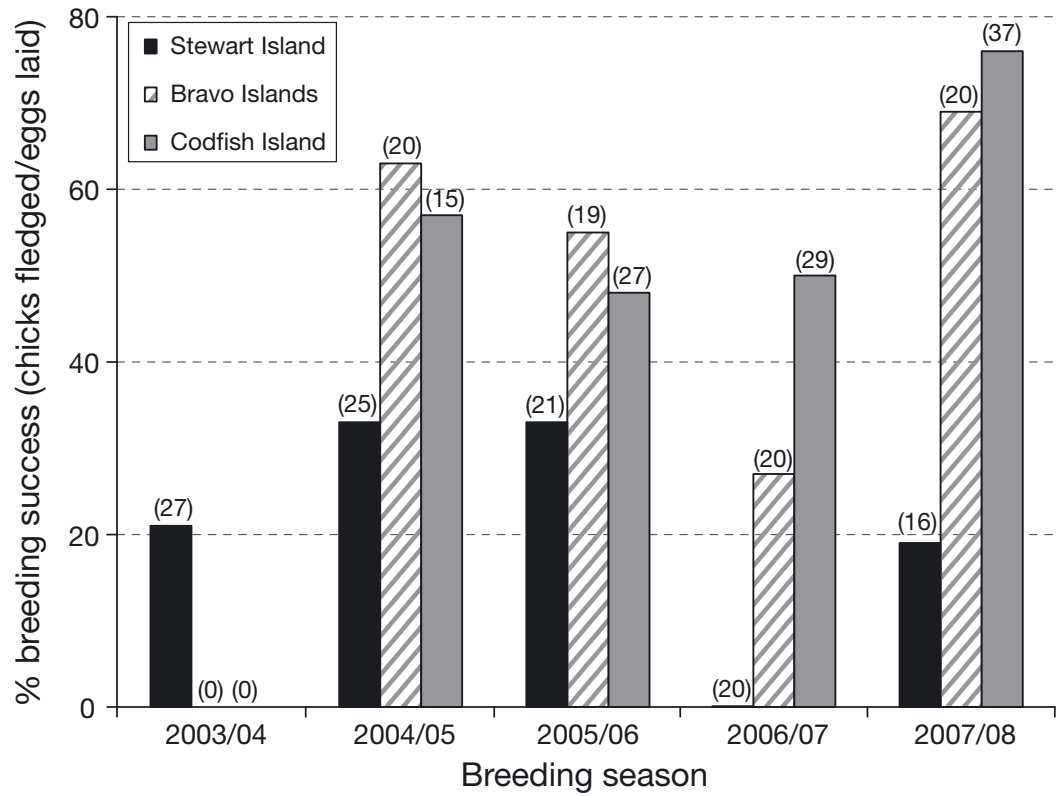

Fig. 2. Megadyptes antipodes. Breeding success of yellow-eyed penguins at 3 sites on northern Stewart Island and nearby islands from 2003 to 2008. The number of nests monitored is given in parentheses 
Vienna PeeDee Belemnite, respectively). The notations $\left(\delta^{13} \mathrm{C}\right.$ and $\left.\delta^{15} \mathrm{~N}\right)$ refer to the enrichment (positive values) or depletion (negative values) relative to these standards.

\section{RESULTS}

\section{Population survey}

We recorded 77 breeding pairs at 21 discrete breeding places throughout Stewart Island in 2008/2009 compared with 79 pairs in 19 discrete breeding locations in 1999 to 2001 (Massaro \& Blair 2003). A shift in distribution was recorded, with some historical breeding places no longer active and new ones emerging. Nest numbers on northern Stewart Island declined by $27 \%$ from 30 to 22 over the same period. The number of breeding pairs recorded on close outlying islands increased from 24 to 30. During the $5 \mathrm{yr}$ of monitoring breeding success, the incidence of nests not located during the initial search period ranged from 7 to $15 \%$. Repeat visits in the course of monitoring allowed us to locate these nests, ensuring certainty about the number of nests at each breeding place. Using the more cautious figure of $15 \%$ error, the population estimate for yellow-eyed penguins on Stewart Island and its close outliers in 2008 is 107 to 123 breeding pairs.

\section{Reproductive success and causal factors}

We monitored 109 yellow-eyed penguin breeding pairs on northern Stewart Island over 5 breeding seasons, and 79 breeding pairs on the Bravo Islands and 108 on Codfish Island over 4 breeding seasons (Fig. 1). These figures represent the total known number of breeding pairs on northern Stewart Island and the Bravo Islands, and a sample of breeding pairs on Codfish Island.

\section{Reproductive success}

The mean reproductive success of yellow-eyed penguins on Stewart Island over 5 yr was $22.0 \%$, significantly less (Kruskal-Wallis $H=9.3$, df $=2$, p = 0.0095) than for the $4 \mathrm{yr}$ that Bravo Islands (53.9\%) and Codfish Island (59.3\%) were monitored (Fig. 2). Reproductive success was particularly poor in the 2006/07 season; no chicks fledged on northern Stewart Island.
The loss of productivity occurred during chick rearing. There was no significant difference between the observed and expected frequencies of hatching success at the 3 sites $\left(\chi^{2}=0.36, p=0.83\right)$, but a highly significant difference occurred between observed and expected frequencies of fledging success $\left(\chi^{2}=\right.$ 23.42, $\mathrm{p}<0.0001)$. During chick rearing, a significantly higher frequency of chick deaths occurred during the guard stage on Stewart Island than at the other 2 sites $\left(\chi^{2}=25.25, p<0.0001\right.$, Fig. 3$)$. There was no difference between the observed and expected frequencies of chick deaths during the post-guard stage at the 3 sites $\left(\chi^{2}=1.61, p=0.45\right)$. In fact, over the monitoring period, a smaller percentage of chicks died on Stewart Island during the guard stage than on the Bravo Islands.

\section{Factors affecting reproductive success}

Over the $5 \mathrm{yr}$ of monitoring on northern Stewart Island, 124 chick deaths occurred within the guard stage. Depredation was definitely ruled out for all but $17(13.7 \%)$, and these were chicks that could not be found (Table 1). In fact, depredation was only confirmed in 1 chick, in the post-guard stage, on Bravo Island and was attributed to weka. On Stewart Island, where cause of death was identified $(\mathrm{n}=50)$, most guard-stage chicks presented with several conditions which caused or contributed to their death.

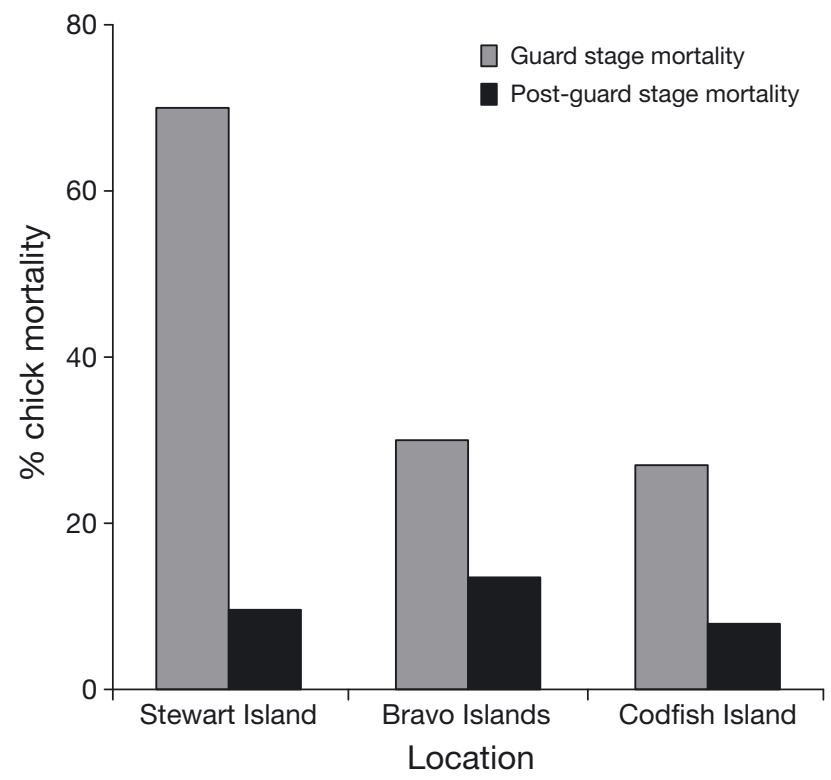

Fig. 3. Megadyptes antipodes. Percentage mortality of yellow-eyed penguin chicks during the guard stage and postguard stage at 3 sites on northern Stewart Island and nearby islands from 2003 to 2008 
Primary causes identified included starvation ( $\mathrm{n}=17$, $34 \%$ ) and disease $(n=16,32 \%)$. Parental trauma or accident was the next most common cause $(\mathrm{n}=12$, $24 \%$ ). On the 2 island sites, 64 of the 93 dead chicks from the guard stage could not be found (68.8\%). Limited data on the causes of chick death were collected from the island sites due to infrequent visits to nest sites. Chick carcasses decayed quickly and became almost indistinguishable from nest material or disappeared completely after only a few days, and on the Bravo Islands carcasses may have been removed by scavenging Stewart Island weka. Of the remaining dead chicks from these 2 sites, no particular identified cause of death predominated, and disease is only known to have caused 3 chick deaths (Table 1). The observed and expected frequencies of identified chick deaths caused by starvation and disease combined differed significantly between northern Stewart Island and the other 2 sites $\left(\chi^{2}=46.19\right.$, $\mathrm{p}<0.0001)$.

Of all possible models tested to determine the causal factor with the largest effect on nest success during the guard stage, the 'disease' parameter provided the best fit and had an inverse relationship with nesting success $\left(\mathrm{R}^{2}=55.38, F_{1,11}=13.65, \mathrm{p}=\right.$ $0.004)$. Inclusion of any of the other causes of mortality did not improve the fit.

Of the diseases, 2 infectious diseases were identified: diphtheritic stomatitis and infection with Leucocytozoon, a haemoparasite. Outbreaks of diphtheritic stomatitis causing widespread chick mortality have previously been recorded in areas of the South Island in 2002 and 2004, but Leucocytozoon infection had not been recorded in yellow-eyed penguins prior to this study (Alley 2005).

For chick deaths during the post-guard stage at all 3 sites, no particular identified cause of death predominated.

Pre-fledging (February) chick weights on northern Stewart Island (mean \pm SD $5.4 \pm 0.6 \mathrm{~kg}$, range $4.1-$ $6.7 \mathrm{~kg}, \mathrm{n}=47$ ) were significantly heavier (ANOVA, $\left.F_{2,296}=40.19, \mathrm{p}<0.0001\right)$ than on the Bravo Islands (mean $4.6 \pm 0.8 \mathrm{~kg}$, range $2.8-6.4 \mathrm{~kg}, \mathrm{n}=92$ ) and Codfish Island (mean $4.8 \pm 0.7 \mathrm{~kg}$, range $2.3-6.4 \mathrm{~kg}$, $\mathrm{n}=158)$. Most chicks weighed in February were deemed healthy on examination.

\section{Food supply}

Analyses of ratios of isotopes of carbon $\left(\delta^{13} \mathrm{C}\right)$ and nitrogen $\left(\delta^{15} \mathrm{~N}\right)$ of down from 3 to 4 wk old chicks and dead chicks suggested differences in the chicks' diet among the 3 sites. In 2007, the analyses also showed a highly significant difference in the $\delta^{15} \mathrm{~N}$ (ANOVA, $F_{2,29}=9.59, \mathrm{p}=0.0006$ ) and $\delta^{13} \mathrm{C}$ values (ANOVA, $\left.F_{2,29}=9.68, \mathrm{p}=0.0006\right)$ for the chicks that died on northern Stewart Island (mean $\delta^{15} \mathrm{~N}=16.42, \delta^{13} \mathrm{C}=$ -16.3) versus both the Codfish Island (mean $\delta^{15} \mathrm{~N}=$ 14.1, mean $\delta^{13} \mathrm{C}=-16.0$ ) and Bravo Islands chicks (mean $\delta^{15} \mathrm{~N}=15.5$, mean $\delta^{13} \mathrm{C}=-15.9$ ) that fledged. The fledged chicks were reared on food that originated from more benthic and/or inshore sites, which are generally more productive and from a lower trophic level (France 1995). Within the group of Stewart Island chicks that died in 2007, 2 distinct groupings were observed. Chicks from Rollers Beach to Golden Beach (Fig. 1) were also being fed from more benthic sites and lower in the food chain than the chicks from Long Harry to Yankee River (Fig. 1). Starvation was the cause of death for $70 \%(n=7)$ of the chicks that died at breeding places from Long Harry to Yankee River in 2007, while parental trauma ( $\mathrm{n}=2,22 \%)$ and infectious disease $(\mathrm{n}=3$, $33 \%$ ) were the most prevalent primary causes of death for chicks from Rollers Beach to Golden Beach.

\section{DISCUSSION}

\section{Causes of chick mortality}

The hypothesis that depredation by feral cats was the principal cause of low reproductive success and population decline of yellow-eyed penguins on northern Stewart Island was not supported by our results. However, low reproductive success was recorded resulting from chronic high chick mortality during the guard stage. Factors affecting breeding success of yellow-eyed penguins on northern Stewart Island were localised and not apparent in other Stewart Island colonies. This was also expressed in the census results, with a decline in the northern Stewart Island colonies over 9 yr that was not mirrored elsewhere.

This conclusion does not exclude the possibility that cats depredate yellow-eyed penguin chicks from time to time. Ratz et al. (1992) suggested that the chance appearance of particular 'rogue' individuals amongst the feral cat population may account for sporadic predation on yellow-eyed penguins at South Island sites, and similarly, Powlesland et al. (1995) suggested that depredations by a few individual cats resulted in the decline of the kakapo population on southern Stewart Island. The 17 penguin chick carcasses that we were unable to locate may 
have been depredated and removed from the nest area by feral cats. However, there is no conclusive evidence of this, and several other likely scenarios exist: (1) Very small chicks (<200 g) decomposed quickly under an incubating adult and became indistinguishable from nest material. (2) At or shortly before ca. 20 d old, chicks begin making short forays from the nest bowl (Darby \& Seddon 1990). Several chicks were found dead a short distance from the nest, and it is possible that missing chicks had also wandered but had become lost in dense undergrowth. (3) Carcasses of missing chicks may have been removed by scavengers. However, the most compelling evidence that depredation is not a principal cause of low reproductive success is the number of chick carcasses found that exhibited no evidence of depredation, and the effect of disease on the northern Stewart Island sub-population in particular.

Other possible, but less likely, reasons exist for the observed decline on Stewart Island. For example, depletion of the understorey around nesting sites by browsing animals like introduced white-tailed deer appears unlikely, as these browsers do reach some inshore islands and can quickly strip the understorey, with no apparent ill effect on penguin numbers ( $\mathrm{S}$. King pers. obs.). Human visitation and disturbance is similarly unlikely, as nesting sites on the offshore islands and the main island are equally isolated and inaccessible. Information on accidental captures of yellow-eyed penguins by fisheries is scant and is likely to be under-reported (Darby 2003), but would probably affect both Stewart Island and outlying island populations equally. The effects of marine perturbations due to climatic events like El Niño and La Niña are well known, but are also likely to affect all populations equally (Darby 2003, Massaro \& Blair 2003).

Infectious diseases were a significant cause of chick mortality on northern Stewart Island during the guard stage. They were also identified as a cause of chick mortality on Codfish Island and the Bravo Islands, but their prevalence at these sites is unknown. During this study, the blood parasite Leucocytozoon was discovered in yellow-eyed penguin adults and chicks at the Stewart Island study site, but not in birds on Codfish Island or the South Island, although Hill (2008) noted that small sample sizes may have reduced the chance of detection at these sites. The prevalence of Leucocytozoon sp. on Stewart Island ties in with high chick mortality there and suggests that localised factors are affecting this subpopulation. Infected adults on Stewart Island showed no clinical symptoms but are probably acting as a reservoir source for ongoing infection. The expression of clinical symptoms is likely to be influenced by various stressors, including concurrent infection and nutritional stress (Hill 2008), which suggests a relationship between food supply and the expression of disease.

The presence of Leucocytozoon raises questions about the parasite's prevalence and role in yelloweyed penguin reproductive success. Leucocytozoon is one of several genera of blood parasites known to affect avian species worldwide and has been linked to decreased reproductive success in some species (Hill 2008). Hill (2008) suggested that the Leucocytozoon species infecting yellow-eyed penguins is another, as yet unnamed, species that may be endemic in the yellow-eyed penguin population. Transmission is by a vector, often simuliid flies such as the sandfly Austrosimulium ungulatum, a biting blackfly plentiful in coastal areas of Stewart Island (Hill 2008).

The geographical extent and prevalence of Leucocytozoon sp. in the yellow-eyed penguin population requires further study, as does its relationship with food supply, the triggers for expression of clinical symptoms and its potential impact on adult penguins in times of stress such as moult. The latter may be of particular importance, as higher than expected mortality of breeding adults can significantly hasten the decline of a population.

We had expected that penguin diet would be of similar quality at all 3 study sites, but stable isotope analyses recorded dietary differences between the sites, which correlate with the incidence of chick mortality. In this case, it should be noted that the physiology of starvation can deplete stable isotope ratios in diet-restricted seabirds (Williams et al. 2007, Sears et al. 2009). However, both of these studies also concluded that both the variation within feather stable isotope ratios and ecological variation were large relative to the effect of starvation, so ecological inferences could still be drawn from feathers, albeit with some caution.

Chicks which were fed a better-quality diet had a higher rate of fledging, suggesting that dietary conditions were influencing reproductive success. Paradoxically, the mean pre-fledging weight of chicks from northern Stewart Island was greater than the mean pre-fledging weights of chicks from both Codfish Island and the Bravo Islands, which might suggest a better diet for the Stewart Island chicks. However, Williams \& Croxall (1990) suggested that in years when food supply is poor, the mean fledging weight of gentoo penguins was higher than in 
years when food supply was good, because in poor food years there was significant pre-fledging mortality of lighter chicks. In good food years, more lightweight chicks survived to fledging, and the inclusion of their weights lowered the overall mean. Records of chick fledging weights from our study are consistent with this suggestion, and the weight ranges show that more lightweight chicks survived on Codfish Island and the Bravo Islands than on Stewart Island. However, in this study, differences in mean fledging weights and chick mortality were recorded in the same year at different sites, providing further evidence for a dietary difference between the sites. Furthermore, 2 concurrent studies which looked at foraging behaviour and diet of yellow-eyed penguins from the same sites on Stewart Island and Codfish Island also found evidence to support this conclusion (Mattern 2006, Browne et al. 2011). Adult penguins from the 2 sites foraged in different areas when provisioning chicks, and these foraging patterns persisted from year to year, and the average meal mass, energetic value and prey diversity were greater in the diet of chicks on Codfish Island, with fewer adults returning with empty stomachs (Browne et al. 2011).

\section{Low reproductive success and population decline}

Site-specific effects on colony size due to poorquality prey conditions have been recorded within adjacent Magellanic penguin colonies (Forero et al. 2002, Wilson et al. 2005) and may be the reason for other concurrent diverging colony size changes in other penguin populations elsewhere (Hinke et al. 2007, Ghys et al. 2008, Oehler et al. 2008).

The relationship between the marine habitat and differences in yellow-eyed penguin reproductive success is poorly understood and requires investigation. In other marine bird species, degradation of foraging habitat appears to have caused substantial recorded long-term population declines through chronic poor reproductive success tied to low-quality diet for nestlings (Gutowsky et al. 2009). Northern Stewart Island penguins forage in Foveaux Strait, which differs from other Stewart Island coastal waters both physically and in terms of human activity. Physical differences that may equate to differences in the penguins' marine habitat include water depth, tidal and current flow, substrate type and sediment movement (Cranfield et al. 1999). Human activity in Foveaux Strait mainly relates to fishing activities and transportation between Stewart Island and the South Island. Several types of fishing activity occur within the Strait, including potting, hand lining, set netting, diving and dredging. Most of these activities are widespread around the Stewart Island coast; however, commercial dredging for oysters occurs only within Foveaux Strait. The adverse effects of commercial oyster dredging on the benthic community are well documented (Cranfield et al. 1999, 2001, 2005, Jiang \& Carbines 2002, Cranfield 2007), and dredging is known to reduce benthic biodiversity by simplifying reef structure (Thrush \& Dayton 2002). The prey of yellow-eyed penguins provisioning chicks in northern Stewart Island was almost entirely blue cod Parapercis colias (Browne et al. 2011), a species that is relatively tolerant to dredging (Cranfield et al. 2001). Blue cod appear to be a less profitable and hence, less preferred, prey of yellow-eyed penguins and generally comprise a small portion of yellow-eyed penguin diet in the South Island (van Heezik \& Davis 1990, Moore \& Wakelin 1997), with an apparent inverse relationship between consumption of blue cod and breeding success (van Heezik \& Davis 1990, Moore \& Wakelin 1997). This suggests that blue cod are a poor-quality food for provisioning chicks, with a concomitant reduction in reproductive success. Elsewhere, poor chick growth and reproductive failure in seabirds have been linked to provisioning with poor-quality fish, the socalled 'junk food' hypothesis (Wanless et al. 2005, Romano et al. 2006, Grémillet et al. 2008). Feeding chicks with poor-quality fish indicates a major perturbation in the local marine food web (Davoren \& Montevecchi 2003, Wanless et al. 2005). In this case, a link between the degradation of the benthic habitat in Foveaux Strait as a result of commercial dredging, and a reduction in quality of the penguins' food supply appears likely. Recovery of the diversity of benthic habitat in Foveaux Strait after dredging had ceased for 3 yr in 1993 (Cranfield et al. 2001) suggests that experiments with fisheries management could answer whether current fisheries activities are causing the decline of the northern Stewart Island yellow-eyed penguin population. Where commercial fishery activity has been restricted elsewhere, penguin foraging effort and daily energy expenditure can be markedly reduced, in contrast to areas where commercial fishing continues (Pichegru et al. 2010), which may allow marine habitat and penguin populations to recover. Similar closures off the north coast of Stewart Island could conceivably be trialled, and yellow-eyed penguin breeding success, and indeed benthic habitat, could be monitored to determine any improvement. 


\section{CONCLUSION}

Yellow-eyed penguins can live for more than $20 \mathrm{yr}$; post-fledging mortality is highest in the first $2 \mathrm{yr}$, but subsequent adult survival is high, averaging $86 \%$, and does not vary significantly with increasing age (Richdale 1957). Once established at a breeding area, adult dispersal is rare (Richdale 1957). The strongly philopatric nature of these birds means that consistently low reproductive success, such as that recorded on northern Stewart Island during this study, will eventually result in low recruitment to the breeding population and an eventual decline through natural attrition. This situation can potentially go unnoticed with the population remaining relatively stable for a number of years, until cohorts of breeders reach the end of their natural life and population decline accelerates. Decreasing nest numbers suggest that the northern Stewart Island sub-population may have reached this stage. Identifying factors that underpin the unusually high chick mortality on northern Stewart Island was therefore a crucial first step in implementing management procedures to arrest the decline.

This research has provided a valuable lesson about the importance of understanding a problem before attempting management, and highlights potential pitfalls in applying generic solutions to local problems. In this case, assumptions about the impact of cats on yellow-eyed penguin chick survival on Stewart Island would have suggested that cat control around penguin breeding areas was required to improve chick survival. Predator control is a key management activity for other yellow-eyed penguin populations. It is also costly and time consuming to implement, and on Stewart Island was unlikely to have affected chick survival.

We recommend further study into factors underlying the identified causes of chick mortality, complemented by monitoring of reproductive success at selected sites, and regular censuses to provide an indication of whether the problems identified on northern Stewart Island remain localised or are manifested elsewhere. If left unchecked, the continued action of these factors may result in the demise of the northern Stewart Island population. The loss of this population, which accounts for approximately $17 \%$ of the entire Stewart Island population and approximately $3 \%$ of the estimated southern New Zealand population, would be significant. Understanding the agents of decline, and most importantly their potential to affect the wider penguin population, is crucial if their impact is to be prevented and managed, both on Stewart Island and elsewhere.
Acknowledgements. This study depended upon financial and in-kind support given to the Yellow-eyed Penguin Trust, and we thank A. Eiselt, Bendigo Valley Foundation, C. and D. Dillon, Church Hill Restaurant, Contact Energy Limited, the Community Trust of Southland, Dancing Star Foundation, Dave's Place, Forensic Solutions Ltd, Foveaux Express, Gribbles Veterinary Pathology, Heritage Expeditions, Just Café, Mainland Brand (Fonterra NZ Ltd), Pacific Development and Conservation Trust, Southland Locator Beacon Trust, Stewart Island Experience (Real Journeys Ltd), Stewart Island Fisherman's Association, Stewart Island Flights, Stewart Island Lions Club, Stewart Island Motels, Stewart Island Water Taxi and Eco Guiding, Telecom NZ, WWF-NZ Habitat Protection Fund, and Yellow-eyed Penguin Trust supporters. Numerous volunteers assisted in the field, and we thank them for their efforts. The Department of Conservation Southland Conservancy supported this study with advice and financial and logistical support, with particular assistance from A. Roberts, B. Beaven and P. McClelland. Yellow-eyed Penguin Trust staff and trustees were always supportive, particularly D. Blair and L. Fraser. M. Chittenden made helpful comments on early drafts. All chick manipulations were approved by the Animal Ethics Committee of the Department of Conservation, New Zealand.

\section{LITERATURE CITED}

Ainley DG, Ballard G, Barton KJ, Karl BJ, Rau GH, Ribic CA, Wilson PR (2003) Spatial and temporal variation in diet within a presumed metapopulation of Adélie penguins. Condor 105:95-106

Alley MR (2005) Leucocytozoonosis in yellow-eyed penguins, Megadyptes antipodes. Kokako 12:31-32

Barbraud C, Weimerskirch H (2001) Emperor penguins and climate change. Nature 411:183-186

Bingham M (2002) The decline of Falkland Islands penguins in the presence of a commercial fishing industry. Rev Chil Hist Nat 75:805-818

Boersma PD (2008) Penguins as marine sentinels. Bioscience 58:597-607

Boersma PD, Rebstock GA, Frere E, Moore SE (2009) Following the fish: penguins and productivity in the South Atlantic. Ecol Monogr 79:59-76

Boessenkool S, Star B, Waters JM, Seddon PJ (2009) Multilocus assignment analyses reveal multiple units and rare migration events in the recently expanded yellow-eyed penguin (Megadyptes antipodes). Mol Ecol 18: 2390-2400

Browne T, Lalas C, Mattern T, van Heezik Y (2011) Chick starvation in yellow-eyed penguins: evidence for poor diet quality and selective provisioning of chicks from conventional diet analysis and stable isotopes. Austral Ecol 36:99-108

Cranfield HJ (2007) Dire Strait - Bluff oysters. NZ Geogr 84: 88-97

Cranfield HJ, Michael KP, Doonan IJ (1999) Changes in the distribution of epifaunal reefs and oysters during 130 years of dredging for oysters in Foveaux Strait, southern New Zealand. Aquat Conserv 9:461-483

> Cranfield HJ, Carbines G, Michael KP, Dunn A, Stotter DR, Smith DJ (2001) Promising signs of regeneration of blue cod and oyster habitat changed by dredging in Foveaux Strait, southern New Zealand. NZ J Mar Freshw Res 35: 897-908 
Cranfield HJ, Dunn A, Doonan IJ, Michael KP (2005) Bonamia exitiosa epizootic in Ostrea chilensis from Foveaux Strait, southern New Zealand between 1986 and 1992. ICES J Mar Sci 62:3-13

> Cunningham DM, Moors PJ (1994) The decline of rockhopper penguins Eudyptes chrysocome at Campbell Island, Southern Ocean and the influence of rising sea temperatures. Emu 94:27-36

Cuthbert R, Cooper J, Burle M, Glass CJ and others (2009) Population trends and conservation status of the northern rockhopper penguin Eudyptes moseleyi at Tristan de Cunha and Gough Island. Bird Conserv Int 19:109-129

Dann P (1994) The abundance, breeding distribution and nest sites of blue penguins in Otago, New Zealand. Notornis 41:157-166

Darby JT (2003) The yellow-eyed penguin (Megadyptes antipodes) on Stewart and Codfish Islands. Notornis 50: 148-154

> Darby JT, Dawson SM (2000) Bycatch of yellow-eyed penguins (Megadyptes antipodes) in gillnets in New Zealand waters. Biol Conserv 93:327-332

Darby JT, Seddon P (1990) Breeding biology of yellow-eyed penguins (Megadyptes antipodes). In: Davis LS, Darby JT (eds) Penguin biology. Academic Press, San Diego, CA, p 45-62

> Davoren GK, Montevecchi WA (2003) Signals from seabirds indicate changing biology of capelin stocks. Mar Ecol Prog Ser 258:253-261

Dowding JE, Murphy EC (1993) Decline of the Stewart Island population of the New Zealand dotterel. Notornis 40:1-13

Efford M, Darby JT, Spencer N (1994) Population studies of yellow-eyed penguins 1993-94. Progress report. Landcare Research Contract Report: LC9495/39. Landcare Research, Dunedin

Ellenberg U, Setiawin AN, Cree A, Houston DM, Seddon PJ (2007) Elevated hormonal stress response and reduced reproductive output in yellow-eyed penguins to unregulated tourism. Gen Comp Endrocrinol 152:54-63

Esler D (2000) Applying metapopulation theory to conservation of migratory birds. Conserv Biol 14:366-372

> Forcada J, Trathan PN, Reid K, Murphy EJ, Croxall JP (2006) Contrasting population changes in sympatric penguin species in association with climate warming. Glob Change Biol 12:411-423

Forero MG, Hobson KA, Bortolotti GR, Donázar JA, Bertellotti M, Blanco G (2002) Food resource utilisation by the Magellanic penguin evaluated through stable-isotope analysis: segregation by sex and age and influence on offspring quality. Mar Ecol Prog Ser 234:289-299

France RL (1995) Carbon-13 enrichment in benthic compared to planktonic algae: foodweb implications. Mar Ecol Prog Ser 124:307-312

Frederiksen M, Wanless S, Harris MP, Rothery P, Wilson LJ (2004) The role of industrial fisheries and oceanographic change in the decline of North Sea black-legged kittiwakes. J Appl Ecol 41:1129-1139

Gardner H, Kerry K, Riddle M, Brouwer S, Gleeson L (1997) Poultry virus infection in Antarctic penguins. Nature 387: 245

Ghys MI, Rey AR, Schiavini A (2008) Population trend and breeding biology of gentoo penguin in Martillo Island, Tierra Del Fuego, Argentina. Waterbirds 31:625-631

Graczyk TK, Cockrem JF (1995) Aspergillus spp. seropositivity in New Zealand penguins. Mycopathologia 131: 179-184
Grémillet D, Pichegru L, Kuntz G, Woakes AG, Wilkinson S, Crawford RJM, Ryan PG (2008) A junk-food hypothesis for gannets feeding on fishery waste. Proc R Soc Lond B Biol Sci 275:1149-1156

Gutowsky S, Janssen JH, Arcese P, Kyser TK and others (2009) Concurrent declines in nestling diet quality and reproductive success of a threatened seabird over 150 years. Endang Species Res 9:247-254

Harper GA (2007) Habitat selection by feral cats (Felis catus) on a temperate, forested island. Austral Ecol 32:305-314

Harraway J (1995) Regression methods applied. University of Otago Press, Dunedin

Hill AG (2008) An investigation of Leucocytozoon in the endangered yellow-eyed penguin (Megadyptes antipodes). MVSc thesis, Massey University, Palmerston North

Hilton GM, Thompson DR, Sagar PM, Cuthbert RJ, Cherel Y, Bury SJ (2006) A stable-isotopic investigation in to the causes of decline in a sub-Antarctic predator, the rockhopper penguin Eudyptes chrysocome. Glob Change Biol 12:611-625

Hinke JT, Salwicka K, Trivelpiece SG, Watters GM, Trivelpiece WZ (2007) Divergent responses of Pygoscelis penguins reveal a common environmental driver. Oecologia 153:845-855

> Hocken AG (2000) Cause of death in blue penguins (Eudyptula m. minor) in North Otago, New Zealand. NZ J Zool 27:305-309

> Inger R, Bearhop S (2008) Applications of stable isotope analyses to avian ecology. Ibis 150:447-461

IUCN (International Union for Conservation of Nature) (2008) 2008 IUCN Red List of Threatened Species. Available at www.iucnredlist.org (accessed on 30 March 2009)

> Jaeger A, Cherel Y (2011) Isotopic investigation of contemporary and historic changes in penguin trophic niches and carrying capacity of the southern Indian Ocean. PLoS ONE 6:e16484

> Jiang W, Carbines G (2002) Diet of blue cod, Parapercis colias, living on undisturbed biogenic reefs and on seabed modified by oyster dredging in Foveaux Strait, New Zealand. Aquat Conserv 12:257-272

Jiguet F, Robert A, Micol T, Barbraud C (2007) Quantifying stochastic and deterministic threats to island seabirds: last endemic prions face extinction from falcon peregrinations. Anim Conserv 10:245-253

Karl BJ, Best HA (1982) Feral cats on Stewart Island; their foods, and their affects on kakapo. NZ J Zool 9:287-294

> Long PR, Székely T, Kershaw M, O'Connell M (2007) Ecological factors and human threats both drive wildfowl population declines. Anim Conserv 10:183-191

Marchant S, Higgins PJ (1990) Handbook of Australian, New Zealand and Antarctic birds. Oxford University Press, Melbourne

Massaro M, Blair DM (2003) Comparison of population numbers of yellow-eyed penguins, Megadyptes antipodes, on Stewart Island and on adjacent cat-free islands. NZ J Ecol 27:107-113

Mattern T (2006) Marine ecology of offshore and inshore foraging penguins: the Snares penguin Eudyptes robustus and yellow-eyed penguin Megadyptes antipodes. PhD thesis, University of Otago, Dunedin

Mattern T, Houston DB, Lalas C, Setiawan AN, Davis LS (2009) Diet composition, continuity in prey availability and marine habitat-keystones to population stability in the Snares penguin (Eudyptes robustus). Emu 109: $204-213$ 
McKinlay B (2001) Hoiho (Megadyptes antipodes) recovery plan. Department of Conservation, Wellington

Moore PJ, Wakelin MD (1997) Diet of the yellow-eyed penguin Megadyptes antipodes, South Island, New Zealand, 1991-1993. Mar Ornithol 25:17-29

Morgan IR, Westbury HA, Campbell J (1985) Viral infections of little blue penguins (Eudyptula minor) along the southern coast of Australia. J Wildl Dis 21:193-198

Oehler DA, Pelikan S, Fry WR, Weakly L Jr, Kusch A, Marin M (2008) Status of crested penguin (Eudyptes spp.) populations on three islands in southern Chile. Wilson J Ornithol 120:575-581

Pichegru L, Grémillet D, Crawford RJM, Ryan PG (2010) Marine no-take zone rapidly benefits endangered penguin. Biol Lett 6:498-501

Powlesland RG, Roberts A, Lloyd BD, Merton DV (1995) Number, fate, and distribution of kakapo (Strigops habroptilus) found on Stewart Island, New Zealand, 1979-1982. NZ J Zool 22:239-248

Pütz K, Clausen AP, Huin N, Croxall JP (2003) Re-evaluation of historical rockhopper penguin population data in the Falkland Islands. Waterbirds 26:169-175

R Development Core Team (2011) R: a language and environment for statistical computing. R Foundation for Statistical Computing, Vienna

Ratz H, Moller H, Alterio N, Dymond S, Fechney T, Wass R (1992) Protection of yellow-eyed penguins from predation; first year research report. A report to funding agencies, landowners and research collaborators. Department of Zoology, University of Otago, Dunedin

Richdale LE (1942) A comprehensive history of the behaviour of the yellow-eyed penguin (Megadyptes antipodes) Homb. and Jacqu. MS 1260/70/1,2. Hocken Library, Dunedin

Richdale LE (1957) A population study of penguins. Clarendon Press, Oxford

Romano MD, Piatt JF, Roby DD (2006) Testing the junk-food

Editorial responsibility: Hans Heinrich Janssen, Oldendorf/Luhe, Germany hypothesis on marine birds: effects of prey type on growth and development. Waterbirds 29:407-414

Sander MT, Balbão TC, Costa ES, Rodrigo dos Santos C, Petry MV (2007) Decline of the breeding population of Pygoscelis antarctica and Pygoscelis adeliae on Penguin Island, South Shetland, Antarctica. Polar Biol 30:651-654

Sears J, Hatch SA, O'Brien DM (2009) Disentangling effects of growth and nutritional status on seabird stable isotope ratios. Oecologia 159:41-48

Sturrock HJW, Tompkins DM (2008) Avian malaria parasites (Plasmodium spp.) in Dunedin and on the Otago Peninsula, southern New Zealand. NZ J Ecol 32:98-102

Taylor SS, Leonard ML, Boness DJ, Majluf P (2002) Foraging by Humboldt penguins (Sphenicus humboldti) during the chick-rearing period: general patterns, sex differences, and recommendations to reduce incidental bycatch in fishing nets. Can J Zool 80:700-707

- Thrush SF, Dayton PK (2002) Disturbance to marine benthic habitats by trawling and dredging: implications for marine diversity. Annu Rev Ecol Syst 33:449-473

van Heezik Y, Davis L (1990) Effects of food variability on growth rates, fledging sizes and reproductive success in the yellow-eyed penguin Megadyptes antipodes. Ibis 132:354-365

> Wanless S, Harris MP, Redman P, Speakman JR (2005) Low energy values of fish as a probable cause of a major seabird breeding failure in the North Sea. Mar Ecol Prog Ser 294:1-8

Williams CT, Buck CL, Sears J, Kitaysky AS (2007) Effects of nutritional restriction on nitrogen and carbon stable isotopes in growing seabirds. Oecologia 153:11-18

Williams TD, Croxall JP (1990) Is chick fledging weight a good index of food availability in seabird populations? Oikos 59:414-416

> Wilson RP, Scolaro JA, Grémillet D, Kierspel MAM and others (2005) How do Magellanic penguins cope with variability in their access to prey? Ecol Monogr 75:379-401

Submitted: June 16, 2010; Accepted: July 30, 2012

Proofs received from author(s): October 20, 2012 